\title{
Surfaces
}

\section{NATIONALISM AND ÉCRITURE}

\section{Kojin Karatani}

Volume 5, 1995

\section{DEUXIÈME CONGRÈS INTERNATIONAL SUR LE DISCOURS HUMANISTE (1995)}

SECOND INTERNATIONAL CONFERENCE ON HUMANISTIC DISCOURSE (1995)

URI : https://id.erudit.org/iderudit/1064990ar

DOI : https://doi.org/10.7202/1064990ar

Aller au sommaire du numéro

\section{Éditeur(s)}

Les Presses de l’Université de Montréal

\section{ISSN}

1188-2492 (imprimé)

1200-5320 (numérique)

Découvrir la revue

\section{Citer cet article}

Karatani, K. (1995). NATIONALISM AND ÉCRITURE. Surfaces, 5. https://doi.org/10.7202/1064990ar
Résumé de l'article

Dans le sillage de Jacques Derrida et de sa critique du phonocentrisme occidental, cet essai avance que le phonocentrisme n'est pas seulement un phénomène propre à l'Ouest, mais est lié à l'émergence de l'État-Nation moderne. Dans ce contexte, cet essai examine, parmi d'autres thématiques, la question du nationalisme et de l'écriture au Japon, tout en discutant la confrontation historique entre les caractères chinois ( $k a n j i)$ et les signes phonétiques (kana), et enfin les écrits du linguiste japonais contemporain Motoki Tokieda.
Ce document est protégé par la loi sur le droit d'auteur. L'utilisation des services d'Érudit (y compris la reproduction) est assujettie à sa politique d'utilisation que vous pouvez consulter en ligne.

https://apropos.erudit.org/fr/usagers/politique-dutilisation/ 


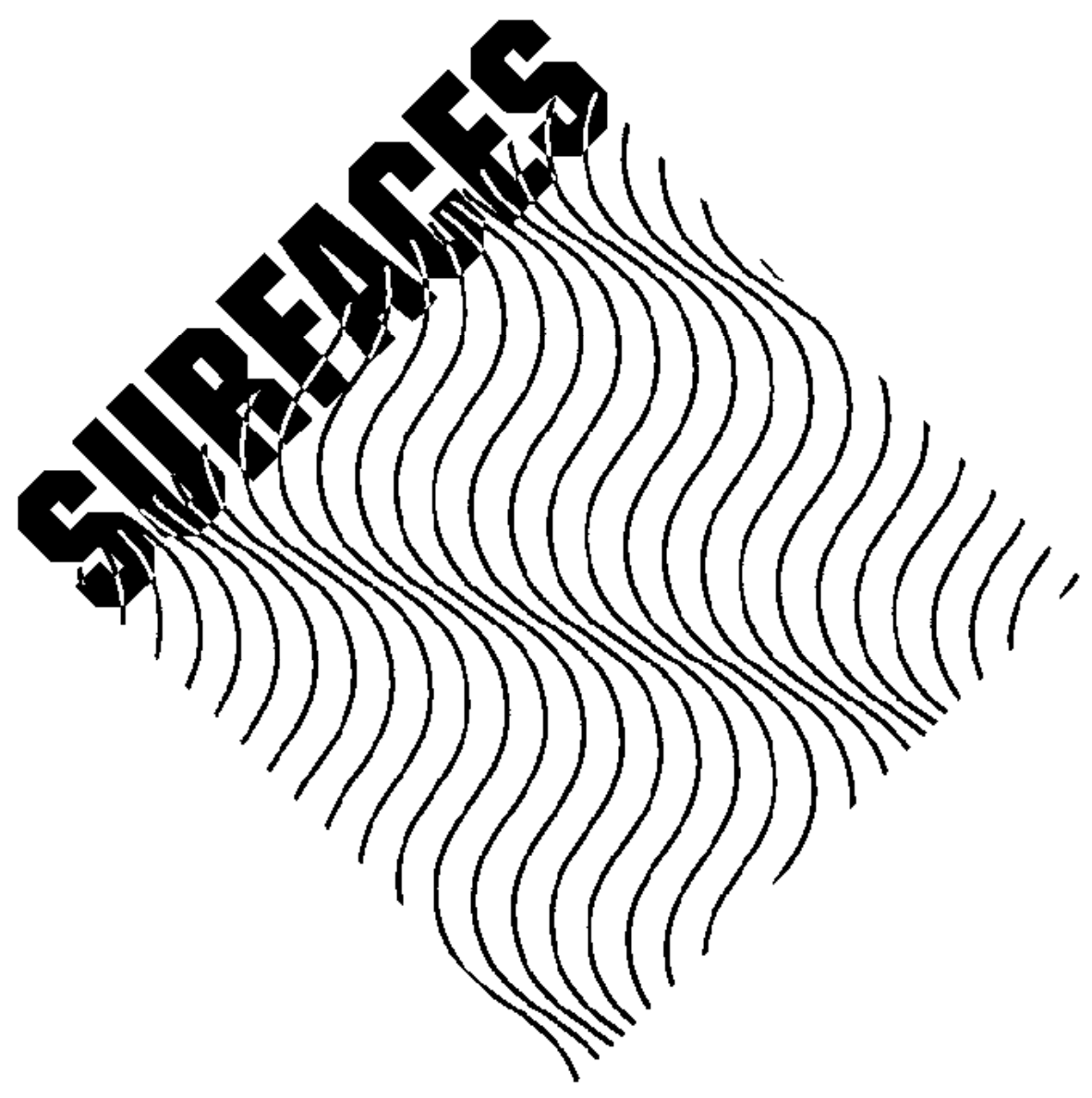

NATiOnALiSM AND

ÉCRITURE

Kojin Karatani 
Nationalism and Écriture (v.1.0 A $-01 / 11 / 95)$ Kojin Karatani

Editor in chief:

Terry Cochran

Editorial Board:

Wlad Godzich

Walter Moser

Michel Pierssens

\section{Technical director:}

Jean-Claude Guédon

\section{Acknowledgments:}

Surfaces would like to thank the following organizations for their support: Apple Canada for providing essential equipment, Industrie Canada, the SSHRC and MESSQ for funding, and the University of Montreal for infrastructural support.

\section{Addresses:}

\section{SURFACES}

Department of Comparative Literature

Université de Montréal

C.P. 6128, succ. Centre-ville

Montreal, Qc, Canada H3C 3J7

Tel.: (514) 3435683

Fax: (514) 3435684

INTERNET Access

via (anonymous) FTP: harfang.cc.umontreal.ca

via Gopher: surfaces@ere.umontreal.ca

via World-Wide Web: under construction

Technical assistance: guedon@ere.umontreal.ca Editorial inquiries: cochrant@ere.umontreal.ca ISSN: $1188-2492$ 
$\underline{\text { Nationalism and Écriture (v.1.0 A } \quad \text { - } 01 / 11 / 95) \text { Kojin Karatani }}$

\section{Submission of Texts}

Articles, reviews and notes may be submitted to the editors by electronic mail, on diskettes, or by mail. Please follow MLA style in matters of presentation and accompany your text with a three or four line abstract.

Any authorial alterations to already published articles must be submitted to the editorial board. Once accepted, an updated version of the article (coded v. 2, with the new date) will replace the original on the electronic network.

Copyright for texts published in SURFACES remains the property of authors. However, any further publication should be accompanied by an acknowledgment of SURFACES as the place of initial publication.

\section{Citation of texts}

Anyone wishing to cite a text from SURFACES should consult the journal at source in order to be sure of using the latest version and base textual references upon the pagination (/pp. $\mathrm{xx} /$ ) inserted in the text rather than upon the foliation (footers). Those without access to electronic mail should contact the editors, who can furnish either a new diskette or printed copy. 
$\underline{\text { Nationalism and Écriture (v.1.0 A } \quad \text { - } 01 / 11 / 95) \text { Kojin Karatani }}$

\begin{abstract}
In referring to Jacques Derrida's critique of Western phonocentrism, this paper argues that phonocentrism is not simply a Western phenomenon but is linked to the emergence of the modern nation-state. In this context, this paper examines the question of nationalism and écriture in Japan, discussing the historical confrontation between Chinese characters (kanji) and phonetic signs (kana), the work of the contemporary Japanese linguist Motoki Tokieda, among other issues.
\end{abstract}

\title{
RÉSUMÉ
}

Dans le sillage de Jacques Derrida et de sa critique du phonocentrisme occidental, cet essai avance que le phonocentrisme n'est pas seulement un phénomène propre à l'Ouest, mais est lié à l'émergence de l'État-Nation moderne. Dans ce contexte, cet essai examine, parmi d'autres thématiques, la question du nationalisme et de l'écriture au Japon, tout en discutant la confrontation historique entre les caractères chinois (kanji) et les signes phonétiques (kana), et enfin les écrits du linguiste japonais contemporain Motoki Tokieda. 
Nationalism and Écriture (v.1.0 A $\quad$ - 01/11/95) Kojin Karatani

1.

Jacques Derrida's Of Grammatology (1967) provided an epochal insight into the problem of écriture (written language). In the 1970s, when I was thinking through the problem of the consolidation of written and spoken language (genbun-icchi) in Meiji Japan, I found this critical work edifying. Yet I had a few doubts about it even then. For instance, Derrida seems to give the impression that phonocentrism dating back to Plato which he criticizes is peculiar to the West. To be sure, the Meiji movement to consolidate written and spoken language, dating back to the proposal to "abolish Chinese characters" made at the end of the Tokugawa period, was certainly influenced by the West. Yet phonocentrism was already present within eighteenth-century nativist scholarship (Kokugaku). It is true that nativist scholarship was initiated by scholars like the Buddhist monk Keich, who were well-versed in Sanskrit, but they certainly had nothing to do with Western metaphysics. The phonocentrism of nativist scholarship saw its ultimate expression in Motoori Norinaga, who opposed the Nihon shoki, written in Chinese characters, with the Kojiki, which appeared to preserve the spoken language of ancient Japan and in which he sought to discover the "ancient way" (Inishie no michi). His disciple Suzuki Akira carried out the first linguistic analysis of classical Japanese. In fact, Motoki Tokieda, who criticized the direct importation of Western linguistics after the Meiji period and sought to establish a linguistics in accordance with Japanese, relied upon Suzuki Akira's pioneering study.

Such being the case, the following can be said: First, we must consider the problem of phonocentrism as one which is not limited to the "West." Second, as in the case of Japan's nativist scholarship, it is something that cannot be divorced from the problem of the modern nation. In Japan, the buds of nationalism appeared first and foremost in the movement to privilege phonetic écriture within the Chinese character (kanji) culture sphere. Yet this situation is not unique to Japan. With respect to the forming of nations, the same problem has emerged all over the world /pp. 5-6/ without exception, 
Nationalism and Écriture (v.1.0 A $\quad$ - 01/11/95) Kojin Karatani

even if such occurrences have not always been concurrent. Thus a historical consideration of the case of Japan should look at the problem of écriture and nation from a more universal perspective, as opposed to the many scholars of Japan who reduce the issue to a matter of Japan's uniqueness.

We must be wary of tracing back to "origins" in the all too distant past. For to do so almost always results in the projection onto the past of an inversion of recent "origin." To trace what Saussure calls "internal linguistics" as far back as the kind of Platonism of which Derrida speaks may appear fundamental, but it overlooks the relatively recent past and the process of political inversion which has taken place therein. In modern Western Europe, phonocentrism emerged not in traditional metaphysics, but rather in a movement which was opposed to it. In other words, it emerged in the attempt to write in the vernacular as opposed to Latin. Large spans of time separate the same effort in different regions. The first to undertake this project in Western Europe was Dante, who not only wrote in the vernacular but also made an effort to attach theoretical significance to the act. Afterwards, the same experiment was undertaken in France, England, Spain, and elsewhere. The matrix of the modern nation takes shape in tandem with the process of creating a written language based on the vernacular. The words written by Dante (Divine Comedy), Descartes, Luther (translation of the Bible), and Cervantes have shaped the languages of each respective nation. In each nation, these classics can still be read today not because the languages of each nation have not changed much, but rather because the languages of each nation have been formed by means of these works.

It goes without saying that Dante's vulgari eloquentia (vernacular) is placed in opposition to Latin, the standard shared language (écriture). Latin is, in other words, the language of "world empire." As in the Roman and Chinese empires, "empire" is multiracial. It is characterized by the use of a shared language such as Latin or Chinese. Furthermore, it is marked by the introduction of a "world religion" that transcends the communal religion/pp. 6-7/ of each racial group. So long as the power relation remains undisturbed, 
Nationalism and Écriture (v.1.0 A $\quad$ - 01/11/95) Kojin Karatani

the "empire" is uninterested in the customs of the various races within it. By contrast, the nation seeks to unify language, and imperialism insists upon homogeneity. In East Asia, Japan belonged to the Chinese character culture sphere of the Chinese Empire. Compared to the fact that Chinese characters and Latin were both the shared languages (écriture) of "world empire," the distinction between characters and the alphabet is of little import. Chinese characters were given different spoken readings in each country, but in Western Europe as well the pronunciation of Latin was not a matter of concern. As écriture, these languages were fundamentally separate from speech.

Modern nations emerge through differentiation within "world empire." We must not look at this process from the side of the political nation-state alone. A separate impetus is needed to create that which is properly termed a "nation." For the nation is rather shaped by "literature" or "aesthetics." As is clear in the case of Dante, the act of writing in the vernacular carries within it a political resistance to Latin, the Roman Church, and thus imperial domination. Phonocentrism contains just such a political motive, which is closely linked to the emergence of the polis/nation.

2.

Derrida perceives phonocentrism in the fact that Saussure excluded written language from linguistics. Yet this is a deconstructive reading of Saussure which tries to show that, by defining language as a system of difference which has no positive terms, Saussure had paradoxically discovered the kind of difference that precedes speech. "Writing appears well before writing in the narrow sense; already in the difference or the arche-writing that opens speech itself." ${ }^{1}$ However, it is not necessary to read /pp. 7-8/

1 Of Grammatology. Trans. Gayatri Chakravorty Spivak. Baltimore: Johns Hopkins University Press, 1976, p. 128.

S U R F A C E S Vol. V.201

folio 7 
Nationalism and Écriture (v.1.0 A $\quad$ - $01 / 11 / 95)$ Kojin Karatani

Saussure exclusively within the context of this critique of "Western metaphysics." To do so is to efface the historical and political connotations of phonocentrism. Saussure himself was most sensitive to this issue.

In the first place, Saussure did not exclude écriture from linguistics because it was secondary to speech. He did so because he knew that écriture had so penetrated spoken language as to be impossible of exclusion. For example, Saussure says the following about language and écriture:

Language and letters. On the one hand they seem to me to be ended, but at the same time it is necessary to make a fundamental distinction between them. Spoken language (mot parlé) alone is the object of linguistics. Diachronic linguistic classifications are only made possible by the fact that a language has been written down. Thus, one cannot altogether deny the importance of letters. In fact, because they are the hallmark of a certain level of civilization, and a certain level of perfection within the use of linguistic activity, written language (langue écrite) even has a reverse effect on spoken language (langue parlée). However, the mixture of spoken and written language has been the cause of innumerable and childish errors in the early period [of linguistics]. (Saussure, Preface to Linguistics)

The speech discussed by historical linguists is already écriture. Linguistics cannot take as its object of study the numerous races and clans of the past who possessed no written language. The fact that a certain language has survived in the form of writing means that it existed as a fixed civilization/state. Such being the case, although one speaks of speech, in fact one is only dealing with the écriture of those races that possessed a certain level of state-form. Moreover, in this case, though it hardly bears saying that écriture does not necessarily transcribe speech, the fact /pp. 8-9/ that speech itself is regulated by écriture is ignored. It is mere 
Nationalism and Écriture (v.1.0 A $\quad$ - 01/11/95) Kojin Karatani

deception for linguists to assume a phonocentric stance in spite of this fact.

A language (langue) cannot die naturally nor in its own proper time. It can only die a violent death. The only means it has of coming to an end, is that of seeing itself removed by force, by a cause absolutely exterior to the facts of language. To give an example by way of the total extermination of a people who speak a language, such will inevitably happen to the languages of the Indians of North America. It also occurs by the imposition of a new language belonging to a stronger race; this necessitates not only political domination, but also a superiority of civilization (and it often requires the presence of a written language which imposes itself on the schools, the churches, the administration, and on all avenues of public and private life). This has been repeated hundreds of times throughout history. ${ }^{2}$

Languages die easily, and they are easily killed off. Written language and the civilization it supports are at work everywhere. Spoken language is constantly under their influence. Historical linguistics looks only at the resulting product, and thus imagines language to be something organic that grows and declines. Thus language merely reflects the growth and decline of a civilization or state. For instance, the idea that Latin was succeeded by French is merely a projection onto language of the inheritance of culture/civilization. In other words, historical linguistics sees culture/civilization and (spoken) language as one and the same thing. It supposes that the arbitrary result of something "external" is in fact the mark of "internal" continuity. Linguistics has taken something external to language, or the result of "external linguistics," /pp. 9-10/ to be the law of language itself. However, in so doing it has ignored the dimensions of the function of that which is external to language.

2 Saussure, Notes sur la linguistique générale, 3288.

S U R F A C E S Vol. V.201

folio 9 
Nationalism and Écriture (v.1.0 A $\quad$ - 01/11/95) Kojin Karatani

Thus it must be said that Saussure's insistence upon "internal linguistics" does not aim at a rejection of the "external," but rather at a criticism of the linguistics which internalizes the product of the "external." By insisting upon "internal linguistics," he in fact exposed the externality of the "external." Stated in other terms, Saussure strictly limited the object of linguistics to spoken language not because of phonocentrism, but rather in order to unmask the deception of historical linguistics' phonocentrism.

Derrida asserts that "The appearance of writing is instantaneous.... Such a leap would prove that the possibility of writing does not inhabit speech, but the outside of speech."3 Yet, as is already clear, this is what Saussure was trying to say by insisting upon "internal linguistics" and distinguishing it from écriture as exteriority. For Saussure, the exteriority of this écriture refers to political relations in the broad sense of the term. We must not reduce this to a textual theory, though Derrida himself would no doubt say that "text" means "context." On the one hand, Saussure is frequently censured on the grounds that he ignored the political nature of language and only treated language as though it were in fact an autonomous system. Yet the exteriority of écriture is in fact nothing but political. What Saussure sought to criticize was the sort of linguistics which effaces that by internalizing it.

The situation Saussure faced was overtly political. It was a situation in which, as a linguist, he could not possibly overlook the ideological function of linguistics itself. The phonocentrism of historical linguistics did not simply emerge at the same time as the idea of national language was on the rise; it in fact served to reinforce that idea. Perhaps Saussure's sensitivity to this /pp. 10-11/ situation stemmed from the fact that he was not a native of France, but rather

3 Of Grammatology, p. 126.

S U R F A C E S Vol. V.201

folio 10 
Nationalism and Écriture (v.1.0 A $\quad$ - 01/11/95) Kojin Karatani

of Switzerland which, while being multiracial, was also a single nation-state, unlike the Austrian Empire.

After that, I would insist upon the singularly clear impact that linguistics has had on ethnography, to the degree that linguistic data is always the first proof for the ethnologist until he is more fully informed. And one wonders why the ethnologist, without this data, could never have been able to assert, for example (to choose one example among a thousand), that among the Hungarians the gypsies represent a race entirely distinct from the Magyar; or that in the Austrian empire the Magyar represents, in turn, a race entirely distinct from the Czech and the German; or that, on the other hand, the Czech and the German, who detest each other from the bottom of their hearts, are of very close parentage; or that the Magyar in turn is a close cousin of the Finnish populations of the Baltic Sea area of the Russian Empire... 4

Of course, Saussure is not simply pointing out the indispensability of linguistics. He is pointing to the political nature of linguistics itself. If a linguist identifies a given language, the result is the existence of a given race. This relation had ruinous implications not only for the Austrian Empire, but also for Switzerland where Saussure gave the lecture. In Switzerland four languages, including French, were recognized as official languages. In the case of French, was it the language of the nation-state of France, or the language of the French people as an ethnic group? In the nation-state of Switzerland, the introduction of concepts of state and ethnicity could only bring about its own collapse. /pp. 11-12/ This lecture given in Switzerland also speaks to the ideological state of affairs in France and Europe as a whole.

4 Saussure, Première conférence à l'Université de Genève, 3283, N 1.1.

S U R F A C E S Vol. V.201

folio 11 
Nationalism and Écriture (v.1.0 A $\quad$ - 01/11/95) Kojin Karatani

It is said that Saussure returned to Switzerland to take a job as a professor of the Université de Genève because he would have had to obtain French citizenship in order to rise to the rank of full professor at the Collège de France. It is doubtful whether his refusal to naturalize in France can be attributed to Swiss nationalism. Yet we can see it as an adverse reaction to nationalism in France. Surely his decision was not unrelated to the work, What is a Nation?, written by Renan in 1882, or to the circumstances which necessitated the writing of such a work.

Renan showed that a nation is not rooted in "race, language, material profit, religious affinity, geography, or military necessity." According to Renan, a nation is rooted in the "emotions" of glory and sorrow, but especially sorrow, shared by people. Put in other words, a nation is based on sympathy or compassion. Of course, these ideas are themselves historical and emerged within Romanticist "aesthetics." They are not necessarily particular to the West. Motoori Norinaga also took the sympathy of mono no aware (a form of pathos based on the nativist view of classical Japanese literature) as his point of departure. If "aesthetics" is that which sees "emotion" as something fundamental and superior to the intellectual or moral, then nation is "aesthetic" from the very outset.

The problem is that when Renan wrote this essay, nation was being objectified in the direction of the essential homogeneity of "race, language, etc.," and through this very process the nation itself was beginning to collapse internally. Thus one could say that underlying Renan's sense of alarm is the process by which nineteenth century nationalism was transformed into imperialism. In fact, his fears were later confirmed by the Nazi Third Reich (the sublimation of the modern nation-state by the Aryan race). Renan issued a warning to the effect that the various "scientific" disciplines of his time (linguistics, ethnography, genetics) were playing a supporting role to that tendency, in contradiction to their /pp. 12-13/ original intentions. Hannah Arendt, for instance, has shown that the demarcation of an Indo-European language family by comparative 
Nationalism and Écriture (v.1.0 A $\quad$ - 01/11/95) Kojin Karatani

linguistics became an ideology for "scientifically" supporting anti-Semitism (Anti-Semitism, 1948). Within Saussure's critique of historical linguistics, there is clearly a critique of that ideological function. More pernicious than Saussure is the posture of disciplinary neutrality which remains insensible to that function.

The ideology of phonocentrism brings into existence ethnicities and races which were heretofore mutually unrelated and therefore nonexistent. In other words, by eliminating écriture/civilization, phonocentrism eliminates "history." For instance, the concept of Eurocentrism develops by means of erasing the influence of the Arab world, which was a "superior civilization" in comparison to the "West." The most expedient means of achieving that erasure is to call upon the difference between Aryan and Semitic languages. It is the phonocentrism of historical linguistics itself which effaces the exteriority of "écriture" or "history." Clearly, Saussure rejected the concepts of "parent language" and "child language" because such linguistics has a political function.

For Saussure, French and Italian are the languages of nation-states, which are basically écriture. In fact, at the time of the French revolution, an announcement was made to the effect that only about 40 percent of the people living in France spoke French. Thereafter the French language spread, in conjunction with the state education system, to the point of exterminating a diversity of spoken languages. This process takes place everywhere (not excluding modern Japan). Saussure excludes écriture not because of his own phonocentrism, but rather to expose the deception by which phonocentrism tacitly internalizes written language and therefore the nation-state. Such being the case, then what sort of spoken language is not mediated by written language and the nation-state?

Everywhere we notice the divisions of dialect. They are often veiled from us by the circumstance that /pp. 13-14/ one among the different dialects was taken to be the literary language, the official administrative language, the language of 
$\underline{\text { Nationalism and Écriture (v.1.0 A } \quad \text { - } 01 / 11 / 95) \text { Kojin Karatani }}$

the traffic and intercourse among the different parts of the country - a preeminent situation which causes that single dialect alone to reach us in written monuments, or which causes the other dialects to be considered as horrible and deformed gibberish that one imagines to be the corruptions of the official language. In the end, it often happens that the language adopted as the literary language ends up killing the other dialects.

The consequence of this observation is that between what one names as two langues, as opposed to two dialects, a boundary does not normally exist (when these langues are of the same origin and are spoken by contiguous and sedentary populations). For example, no boundary exists between French and Italian, between the dialects that one would want to call French and those one would want to call Italian. Just as there are no delimited dialects, there are no delimited langues under normal conditions. Thus langue which, as we have seen, is not a definite notion of time, is also not a definite notion of space. There is no way to fix that which one wishes to say in speaking about this particular langue or that, other than to say "the langue of Rome in this year, the langue of Annecy in this year." Which is to say that one must take up a single, inextensive locality and a single point in time. ${ }^{5}$

The spoken language Saussure seeks out is a plural language, as idiom, in which even the boundaries between languages are unclear. Yet it is not the sort of thing which can be ascertained through a so-called survey of dialects. This idiom exists only in theory. Langue is not écriture, but neither is /pp. 14-15/ it spoken language. Much less is it the language of the nation-state. When Saussure himself explains langue, he uses the examples of

5 Saussure, Notes sur la linguistique générale, 3285.

S U R F A C E S Vol. V.201

folio 14 
Nationalism and Écriture (v.1.0 A $\quad$ - 01/11/95) Kojin Karatani

French and English, which then laid the foundation for misinterpretation. Langue is not (nation-)state language, but rather should refer to the kind of language which is extinguished by state language and which, furthermore, cannot clearly manifest the boundaries between them either spatially or temporally. In this regard, it is a mistake to think that Bakhtin succeeded in criticizing Saussure through his introduction of polyphony. Langue is proclaimed for the purpose of rejecting the establishment of determined rules and criteria.

Saussure emphasized the fact that langue exists through differences which have no positive terms. This should not be interpreted as a system theory or a structuralist stance. The latter mode of thinking was common in mathematics and had no need for Saussure in particular. In fact, what was later called "structuralism" has been pinned to Saussure's name, but its origin can be traced back to mathematics via Jakobson and Levi-Strauss. Thereafter, langue became the model for a closed structure. Furthermore, the idea that language gives structure to the chaos of reality is not original to Saussure - it is simply a variation, via Durkheim, on Kant's distinction between the "thing itself' and the "phenomenon" constructed by form.

Saussure is set apart from the others by his statement that language has nothing positive in it. What is important for him is to reject the idea that language is somehow "clear-cut." Because écriture positively turns langue into something clear-cut, he excludes it from his linguistics in which langue has no distinct boundaries in either spatial or temporal terms. The act of recording a certain dialect, for instance, makes that dialect clear-cut and even normalizes it. The positive specification of langue would transform it into something normative, even if it weren't the state language. Of course, language is a social norm which transcends individual will. Or rather, it is where the subject called the "individual" takes shape. But it is not the same thing as a specified norm. $\quad$ /pp. 15-16/ 
Nationalism and Écriture (v.1.0 A $\quad$ - 01/11/95) Kojin Karatani

Romantics stress that the individual is within language, defined as the "spirit of the race." This is not what Saussure is saying. Language as racial spirit is language as an already specified norm. Romanticism pushes language to the fore, but only to privilege the commonality of "emotion" (sentiment, pathos, or what Heidegger calls being). But this commonality itself is a modern product. Consistent with his rejection of the notion of language as something positive or limited, Saussure rejects the "subject" with regard to language because the subject is enclosed within the nation from the outset.

But if nothing can be said positively, then people have no choice but to abandon "linguistics." In fact, Saussure himself turned to silence. Jakobson opposes Saussure's claim that there is nothing positive in language. He did so, of course, because he was a linguist. Structuralism can only be applied to a fixed, positively closed system. But Saussure's "internal linguistics," no matter what else it may be, is the critique of precisely this hypothesis of a fixed language. For such a hypothesis immediately assumes a political function.

Yet what is the langue of which Saussure speaks, the langue which isn't born, doesn't age, doesn't die, but simply "is"? With any language, it is the very state in which words are currently spoken. It has no meaning beyond that. Any national language may perish, but even so langue doesn't die. Saussure is speaking of the final limit. The complete extinction of mankind is not impossible; but as long as people are people, there will be langue. This is the meaning of his work, stated in other terms.

It is not possible that Saussure could have seen the potential of future linguistics in this sort of "internal linguistics." To push "internal linguistics" to its logical extreme is simply to show that everything beyond it is "external." Ironically, the Saussure who has been read as the founder of the discipline which excludes the "external" was himself conscious of that which is most/pp. 16-17/

S U R F A C E S Vol. V.201

folio 16 
Nationalism and Écriture (v.1.0 A $\quad$ - 01/11/95) Kojin Karatani

"external" - the political. It must be said that after Saussure, only external linguistics has survived.

3.

The phonocentrism of Japan's eighteenth-century nativist scholars contains within it a political struggle against the domination of Chinese "culture," or a bourgeois critique of the samurai system since Chinese philosophy was the official ideology of the Tokugawa shogunate. In an effort to find a Japanese that preceded Chinese characters, as well as the "ancient way" that would correspond to it, nativist scholars looked to works written between the seventh and eleventh centuries such as the Man'yoshuu, the Kojiki, and the Tale of Genji. But they totally lost sight of the fact that such écriture did not begin as an effort to record speech, but rather as an attempt to translate written Chinese into Japanese.

When Dante wrote in the vernacular, he did not directly transpose contemporary spoken language into writing. From the various idioms (Saussure) existing all over Italy, he selected one. It is not because he selected the standard idiom, but rather because he wrote in the vernacular as a form of translating Latin, that his écriture later became the standard écriture. That act relegated the other idioms to the status of dialect. The same can be said in the cases of French and German. The vernacular was written so as to "resemble" Latin and Greek as much as possible. In the case of France, for instance, the Académie Française was established in 1635 for the purpose of "giving a clear set of rules to the national language, making it pure, eloquent, and capable of handling the arts and academic disciplines." It is wrong to think of this as a reformation of the French language, however. As I said above, "French" did not exist as a spoken language; it was simply that written "French" later became the spoken language. "French" as écriture existed as a translation of Latin, which is precisely why it became a language "capable of handling the arts and academic disciplines." It is for this reason that Descartes wrote in both French and Latin, and that his French became the norm. Latin, /pp. 17-18/ which was no more than 
Nationalism and Écriture (v.1.0 A $\quad$ - 01/11/95) Kojin Karatani

a single idiom of the Italian provinces, became a language "capable of handling the arts and academic disciplines" because of its development as a translation of Greek written documents, a process in which the Greeks themselves participated.

The same is true of ancient Japanese. Contrary to a widespread and foolish misconception, Chinese characters are not simply ideographic, but also contain a phonetic element. Thus, among the many races within the Chinese character culture sphere there were various attempts to employ Chinese characters as phonetic signs (kana). Yet Japan was ultimately the only country to absorb Chinese characters into its écriture. Other neighboring states either abandoned Chinese characters or, like modern-day Korea (North and South), are currently in the process of abandoning them. In the case of Korea, for instance, Chinese characters were adopted just as they were spoken (albeit their pronunciation was Koreanized). And Chinese characters were the dominant form of écriture - even though the phonetic hangul alphabet was invented in the fifteenth century, it was hardly used. In Japan, by contrast, Chinese characters were also read with Japanese meanings and pronunciations (kun). This kind of écriture, known as the mixture of Chinese characters with kana phonetic signs (kanji-kana konko), can already be found in the eighth-century Kojiki. Contrary to the opinions of nativist scholars, the language of the Kojiki did not transpose the contemporary vernacular into writing; rather, it was a translation into the vernacular based on the official history of the Nihon shoki, written entirely in Chinese characters, which had been attempted earlier. The Chinese characters employed phonetically at this time were soon abbreviated into a syllabary known as kana. Needless to say, at that time and thereafter Chinese characters existed as "true letters" (ma-na, in opposition to ka-na, literally "provisional letters"). Because of this, écriture in the kana syllabary is called "women's writing." In fact, this écriture gave birth to a great deal of women's literature after the tenth century. Nevertheless, Japanese écriture is fundamentally the combined usage of Chinese characters and the kana syllabary. /pp. 18-19/ 
Nationalism and Écriture (v.1.0 A $\quad$ - 01/11/95) Kojin Karatani

The nativist scholars perceived the true "spirit of Yamato" in the literature by women written purely in the kana syllabary. To be sure, Murasaki Shikibu excludes Chinese words from the Tale of Genji in a highly conscious manner. In a court which operated under the ritsuryo political and legal system introduced from China, and which had also been permeated by Buddhism, Chinese words must have been used on a daily basis. During this era, writing in Chinese was also the only "shared language" that had any currency beyond the limits of the Kyoto court. Norinaga perceives a "criticism of "Chinese ideology" in Murasaki Shikibu's rejection of that language. But let us return to the example of Dante: as one reason for choosing to write in the vernacular, he asserts that Latin "is not the appropriate language for love." In that sense, we can say that the language of poetry and prose fiction (monogatari) rejected Chinese words because those genres dealt principally with "love." But the reason that the Genji was widely read even in its own time was not simply because it was written in the vernacular. Murasaki Shikibu was perfectly capable of reading and writing Chinese; even if she intentionally excluded Chinese words from her writing, her work nevertheless normalized the Yamato (Japanese) language as écriture. That écriture probably has little to do with the vernacular language being spoken in Kyoto at the time. However, the écriture of women's court literature, limited to the theme of love or the relations between the sexes, would not have currency in other areas. At that time and ever since, the mainstream of Japan's écriture has been the mixture of Chinese characters and the kana syllabary.

Within the phonocentrism of nativist scholars who criticized this mixture lies a romantic, aesthetic line of thought that aims to privilege emotion and mood above that which is moral or intellectual. Although this phenomenon has nothing to do with the West, it nonetheless runs parallel to the Western trend. It is a "modern" line of thought, as it were. This nativist philology was rejected from the Meiji period onward. Japan's modern philology begins with the introduction of nineteenth-century Western historical linguistics. It consisted in a mechanical application of Western grammar to the agglutinative language of Japanese. /pp. 19-20/ 
Nationalism and Écriture (v.1.0 A $\quad$ - 01/11/95) Kojin Karatani

On the one hand, this project is natural scientistic; on the other hand, it is statist. With the introduction of Saussure in the 1920s there was a minor change in terminology, but the discipline itself remained fundamentally the same - it simply became possible, for instance, to refer to Japanese (the language of the Japanese nation-state) as langue.

This is the context within which Tokieda Motoki consistently criticized Saussure. Needless to say, the Saussure he criticized was nothing more than the notion of Saussure generally accepted at the time. In spite of the title of his major work Kokugogaku Genron (1941, A Study of the National Language), Tokieda therein rejects the view that Japanese is the language of the nation-state or the language of the race. One reason for his stance lies in the fact that he was a professor at Keijo Imperial University in the Japanese colony of Korea. Within the Japanese Empire that subsumed the different races/languages of Taiwan, Korea, Okinawa and the Ainus, the language of Japanese would have to be treated as something separate from race and nation-state. At the same time, Japanese would have to be severed from the culture attendant upon it. In short, Tokieda had an understanding of the multilingual situation that made him an exception in Japan. At the same time, he tried to trace his steps back to the nativists and particularly to the theory of language developed by Motoori Norinaga's disciple, Suzuki Akira. At a glance, this appears to be nationalism. Yet it is the scholars of "national language studies" (kokugogaku) who were in fact romantic and nationalistic. Tokieda simply criticized the application of Western grammar to Japanese (which, for instance, led to a useless discussion of the "subject" in Japanese) and sought a universal theory which could explain Japanese as well.

Against Saussure, who rejected the romantic subject, Tokieda laid the charges of being natural scientistic, analytical, and structuralist. He furthermore perceived in Saussure not only nineteenth century linguistics but also "Western metaphysics." However, as I have already said, this is merely a misunderstanding. Tokieda criticizes Saussure by saying, "Language can /pp. 20-21/

S U R F A C E S Vol. V.201

folio 20 
Nationalism and Écriture (v.1.0 A $\quad$ - 01/11/95) Kojin Karatani

never exist apart from the subject." This criticism may apply to pre-Saussurian historical linguistics or to the Durkheim line of sociology, but it is inappropriate to Saussure himself. Saussure emphasizes the fact that linguistics always begins with the "speaking subject." Within that context, langue is something discovered after the fact, not something which exists objectively. He simply points to the fact that, so long as an understanding of meaning exists between two or more people, langue exists therein. Thus the phoneme, as that which discerns meaning, is differentiated from material speech. Of crucial importance is the form (difference) that discerns meaning. Accordingly, the external difference of speech and writing are not the issue. Language is ever and always value (difference).

Nevertheless, as Jakobson pointed out, we cannot deny the co-presence of a certain nineteenth-century "naturalism" in the Course on General Linguistics compiled by Saussure's students. Jakobson brings in Husserl's phenomenology and produces structure through "phenomenological reduction," as it were. Such is structuralism in the strict sense of the word. Thus, as in the case of Derrida, poststructuralism begins with an internal critique of this kind of phenomenology. In relation to this, we should note the fact that Tokieda's criticism of Saussure frequently quotes from Husserl. Moreover, although he never quoted him, Tokieda took the work of Kitaro Nishida as the basis for his argument. As a case in point, Tokieda's "subject" is not the Cartesian thinking subject, but rather Nishida's "subjective emptiness" or "subject as emptiness."

It is within this context that Tokieda embraces the analyses of Motoori Norinaga and Akira Suzuki. Suzuki demonstrated the distinction between "words" (shi), which have a signifying semantic content, and "linking elements" (ji) such as particles (joshi) and auxiliary verbs (joshi) which, though having no such content, manifest an affective value. Nativist scholars compare these particles to a string that holds the jewels (words) together. In other words, they correspond to the copula in Indo-European languages. Based on this distinction, Tokieda interprets words as objective /pp. 21-22/ 
Nationalism and Écriture (v.1.0 A $\quad$ - $01 / 11 / 95)$ Kojin Karatani

expression and linking elements as subjective expression. $\mathrm{He}$ thereby considered that, in opposition to writing in Western languages, in which the subject and predicate are like two poles supported by the verb "to be," writing in Japanese is unified by the fact that the "words" (objective expression) are always enveloped in "linking elements" (subjective expression). ${ }^{6}$

Yet when we consider the fact that Tokieda not only criticized Western linguistics but even attempted to criticize the "Western thought" that lay behind it, we clearly perceive the influence of Nishida's philosophy. Recently Yujiro Nakamura has read Kitaro Nishida as the "deconstruction" of Western philosophy, invoking Tokieda's linguistics therein.

Deserving of attention is the fact that Nishida's pursuit of a "logic of place" unexpectedly illuminates the "logic of Japanese." It is even more noteworthy in that Nishida himself has not proposed any argument in direct relation to the Japanese language. It is Tokieda Motoki's theory of Japanese grammar that alerts us to the fact that Nishida's "logic of place" is an embodiment of the "logic of Japanese."

What especially connects Tokieda's "language process theory" to Nishida's "logic of place" is the concept of "topos" as the foundation for the function of language. According to Tokieda, "topos" is not unrelated to physical place (space), but it also includes the contents that fill up space. At the same time, it also includes the "stance, mood and emotion of the subject that inclines toward" the matter and scenery that fill up space. Thus, "topos is neither a purely objective world, nor a function of purely /pp. 22-23/

6 Translator's note: for a detailed discussion of the terms sh $i$ and $j i$ in English, see Noaki Sakai, Voices of the Past, pp. 272-74.

S U R F A C E S Vol. V.201

folio 22 
Nationalism and Écriture (v.1.0 A $\quad$ - 01/11/95) Kojin Karatani

subjective inclination, but rather a world integrated by the nominative case." Our concrete experience of language cannot be apprehended anywhere except in this "topos." (Yujiro Nakamura, Nishida Tetsugaku no datsukochiku [Nishida Philosophy's Deconstruction])

This kind of understanding reads the situation backwards. Tokieda was reading Nishida from the very start. And his Study of the National Language (1941) was written in the same context as the symposium on "Overcoming Modernity" (1942). The "logic of Japanese" discussed by Nakamura is ahistorical and deceptive. Tokieda's distinction between words and linking elements, or the claim that words are enveloped by linking elements, was not elicited solely by the fact that Japanese syntax is determined by the sentence-ending. If such were the case, why didn't the same concept emerge from other Altaic languages which possess the same syntax? The answer is simple. The distinction between words and linking elements is rooted in the Japanese écriture in which Chinese characters and the kana syllabary are used together. Those parts which correspond to concepts are inscribed in Chinese characters, and those which correspond to particles and auxiliary verbs are inscribed in kana syllabic symbols. This distinction itself is based on a historical convention in écriture. In actuality, the "logic of Japanese" is based on this history.

This is furthermore related to a historical problem which is not unique to Japanese écriture, but has arisen everywhere in the wake of Romanticism. In Japanese, a certain kind of emotion/mood which does not become a concept is discovered in the particles written in the kana syllabary as "string for the jewels." In Western languages, as typified by Heidegger, that element is found in the verb "to be." This verb is a copula not in the sense that it signifies equivalence, but rather because it "copulates" ideas, so to speak. What Heidegger called "the loss of being" meant the reduction of "being" to a simple, logical copula. Thus his emphasis on "being" is nothing but an emphasis on "emotion/mood" as an /pp. 23-24/ 
Nationalism and Écriture (v.1.0 A $\quad$ - 01/11/95) Kojin Karatani

originating source in opposition to ideas. But, in fact, this is a form of thought which emerged in the wake of Romanticism, wherein lies a common thread with the Japanese nativist scholars' critique of "Chinese ideology." In other words, it is a critique of Latinization that traces its own roots back to ancient Greece.

Heidegger's existentialism is enunciated within a history of philosophy based on Western grammar, but it is rooted in a highly modern problem. In the context of Japanese, the argument did not take the form of existentialism. In a sense, Kitaro Nishida took Buddhist philosophy as his base, and spoke in such ontological terms as "being as nothingness." But in fact those terms were connected to late eighteenth-century nativist thought. In other words, this was already a modern form of thinking. Of course Heidegger and Nishida are different, but this must not be reduced to the difference between Western and Eastern thought. Just as Heidegger joined the Nazis, Kitaro Nishida had a political function as an ideologue for the "Greater East Asia Co-Prosperity Sphere."

At this point it is necessary for us to reconsider the fact that Tokieda severed "Japanese" from race and state. He wrote thus at a time when the Japanese empire was expanding from Taiwan and Korea throughout all of East Asia. "If in fact the domain of the national language and the domain of the Japanese state and the Japanese race were in perfect correspondence, then there would be no problem whatsoever with defining the national language as that language which is used by the Japanese race and put into practice in the Japanese state; but one look at the relationships between state, race and language today clearly shows that to define the national language thus is never anything more than a matter of convenience" (The History of National Language Studies). When Tokieda severed Japanese from race and state, he was conscious of a situation in which Japanese would spread throughout "Greater East Asia" as the dominant standard language. That in itself is a political consciousness.

/pp. 24-25/

S U R F A C E S Vol. V.201

folio 24 
Nationalism and Écriture (v.1.0 A $\quad$ - 01/11/95) Kojin Karatani

Of course, Tokieda was not an imperialist. In fact, he publicly denounced the sort of "national language strategy" which sought to enforce the use of Japanese as a standard language in Korea down to the pronunciation of family and given names. Furthermore, he rejected the notion of extracting Japanese culture and philosophy from the Japanese language. After the war, while scholars of the Kyoto school had to revise their work either publicly or in stealth, he was able to publish A Study of the National Language without making any revisions whatsoever. Indeed, after the war his works were published unaltered, and revisions were also unnecessary. This circumstance does not, however, set Tokieda apart from the advocates of "overcoming modernity." For all of the latter were also criticizing imperialism, and if we look at their work in formalist terms, as Yujiro Nakamura has done, then they still bear reading even today. The problem is that in so doing we turn their political context into an abstraction. By severing Japanese from race and state, Tokieda simultaneously ended up turning the politics of language into a complete abstraction.

translation by Indra Levy

Kojin Karatani

Tokyo

karatani@fujimi.hosei.ac.jp

/p. 25/

S U R F A C E S Vol. V.201

folio 25 